\title{
Assessment of water quality based on diatom indices in a small temperate river system, Kowie River, South Africa
}

\author{
Tatenda Dalu' ${ }^{1 *}$, Taurai Bere ${ }^{2}$ and P William Froneman' \\ 'Zoology and Entomology, Rhodes University, P O Box 94, Grahamstown 6140, South Africa \\ ${ }^{2}$ School of Wildlife, Ecology and Conservation, Chinhoyi University of Technology, P Bag 7724, Chinhoyi, Zimbabwe
}

\begin{abstract}
This study aimed to assess the impact of land use patterns on water quality and benthic diatom community structure and to test the applicability of diatom indices developed in other regions of the world to a small temperate southern African river system. Sampling was conducted at eight study sites along the length of the river on four separate occasions. Multivariate data analyses were performed on the diatom community dataset to specify the main gradients of floristic variation and to detect and visualize similarities in diatom samples in relation to land-use patterns within the catchment. One hundred and twelve (112) diatom species belonging to 36 genera were recorded during the study. Canonical correspondence analysis (CCA) demonstrated that variations in the benthic diatom community structure were best explained by ammonium, nitrate, conductivity, $\mathrm{pH}$, temperature, resistivity and water flow. OMNIDIA was used for calculation of selected diatom water quality indices. A number of the indices, e.g., the trophic diatom index (TDI), eutrophication/pollution index and biological index of water quality (BIWQ), either under- or over-estimated the water quality of the system. With few exceptions, there were no significant correlations ( $p>0.05$ ) between the diatom indices' values and the nutrient variables. The absence of any significant correlations between the diatom indices' values and selected physico-chemical variables suggests that indices developed in other regions of the world may not be suitable for temperate southern African rivers.
\end{abstract}

Keywords: biomonitoring, diatom indices, diatom community, Kowie River, nitrogen, multivariate analysis, point-source pollution, water quality

\section{INTRODUCTION}

Rivers, streams, ponds, lakes and reservoirs constitute an estimated $65 \%$ of freshwater ecosystems worldwide and are regarded as the most vulnerable water systems globally (Vörösmarty et al., 2010; Schowe and Harding, 2014; Tan et al., 2015). Anthropogenic effects, such as increased water consumption, industrial and agricultural activities or urbanisation, and inorganic processes such as erosion, precipitation inputs or weathering of crustal materials, degrade surface waters. This impacts the ecological integrity and functioning of freshwater ecosystems and subsequently impairs their use for domestic, industrial and agricultural purposes (Wu et al., 2012; Venkatachalapathy and Karthikeyan, 2015). Distinguishing and managing dynamic environmental conditions in diverse systems requires a cutting-edge approach taking into account ecological principles; an example of such an approach is biological monitoring.

Diatoms are the main primary producers and chemical modulators in freshwater aquatic ecosystems(Wu et al., 2012; Bere et al., 2014; Dalu et al., 2014a, b; Mangadze et al., 2015) and represent an important carbon and energy source for secondary consumers (Tan et al., 2014a; Venkatachalapathy and Karthikeyan, 2015). Because diatoms are very sensitive to environmental change and/or disturbances such as eutrophication, acidification, land use and pollution, they are considered to be powerful indicators of water quality in freshwater systems (Harding et al., 2005; Taylor et al., 2007a; Walsh and Wepener, 2009; Bere and Tundisi, 2010a; Wu et al., 2012; Rimet et al., 2015). Moreover diatoms have distinct ecological tolerances

*To whom all correspondence should be addressed.

e-mail: dalutatenda@yahoo.co.uk

Received: 12 May 2015; accepted in revised form 12 February 2016
(Bahls, 1993) and short generation time (Zalack et al., 2010; Tan et al., 2014b), making them suitable indicator organisms for water quality changes over short time scales. Diatoms have been employed as water quality indicators in Europe (Kelly et al. 1998; Prygiel et al., 1999), North America (Stevenson and Pan, 1999; Lowe and Pan, 1996; Winter and Duthie, 2000; Lavoie et al., 2006, 2014), South America (Lobo et al., 1996; Bere and Tundisi, 2011), Australia (Chessman et al., 1999; John, 2000), Asia (Lobo et al., 1995; Rothfritz et al., 1997) and, to a lesser extent, Africa (Bellinger et al., 2006; Ndirutu et al., 2006; Taylor et al., 2007a, b; Bere et al., 2014; Mangadze et al., 2015).

Diatom indices are commonly used to summarise ecological and hydrological information provided by diatom assemblages (Almeida et al., 2014), and have been developed and applied for water quality assessment worldwide (Bate et al., 2002; Taylor et al., 2007a, b; Tan et al., 2014b). Most of the indices employed are based on Zelinka and Marvan's (1961) approach, which considers weighted averages of taxa's sensitivity to nutrients and organic degradation, as well as $\mathrm{pH}$ and salinity (Taylor et al., 2007b; Almeida et al., 2014; Bere et al., 2014; Hlúbiková et al., 2014). The simplest indices comprise a single metric which is used to indicate the degree of impact (Taylor et al., 2007a; Schowe and Harding, 2014). Assessments using diatom-based indices can provide a holistic perspective and general indication of the ecological status of a river system (Mistri et al., 2008; Tan et al., 2015). Indices that are regularly used require diatoms to be identified to species level (Bate et al., 2002). This requirement of fine taxonomy, together with the frequent changes in nomenclature, complicate the reliable comparison of diatom-based water quality results, and are an additional reason for inter-calibration (Almeida et al., 2014; Bešta et al., 2015).

Diatom indices have been employed in southern African studies, e.g., Bate et al. (2004), Bellinger et al. (2006), Taylor et 
al. (2007a, b), Walsh and Wepener (2009) and Bere et al. (2013), although to a limited extent. The aim of our study was two-fold: (i) to assess the impact of land-use patterns on water quality and benthic diatom community structure in a small temperate South African river in the Eastern Cape Province of South Africa, and (ii) to test whether routinely employed diatom index values are consistent with observed physico-chemical variables along the length of the river. We hypothesised that changes in water quality resulting from different land use patterns would be reflected in diatom community structure.

\section{MATERIALS AND METHODS}

\section{Study area}

The temperate Kowie River drains a catchment area of approximately $800 \mathrm{~km}^{2}$ and has a total length of $\sim 70 \mathrm{~km}$. Mean annual rainfall is $650 \mathrm{~mm}$, which is evenly distributed over the entire catchment area. Minimum and maximum air temperatures are $1.5^{\circ} \mathrm{C}$ and $43^{\circ} \mathrm{C}$, respectively. Land use in the catchment of the upper to middle reaches of the Kowie River includes pineapple, citrus, chicory and livestock farms. A sewage treatment plant in the coastal town of Port Alfred discharges effluent into the lower reaches of the Kowie River. The study was conducted in September and November 2012, and February and May 2013. Eight sites were selected along the Kowie River system: two sites (F1 and F2) were located in relatively un-impacted forested upper reaches to act as reference sites, two sites (F3 and F4) were polluted by the Bloukrans River which drains Grahamstown and by intensive farmlands along the Belmont Valley area, three sites (F5, E1 and E2) were polluted by JP de Wet Steyn River which drains farmlands, and Site E3 was polluted by effluent from a sewage treatment works in Port Alfred (Fig. 1).

\section{Physico-chemical variables}

A Flo-mate portable flow meter Model 2000 (Marsh McBirney, Maryland) was used to measure water depth and current velocity during each sampling visit. A CyberScan Series 600 portable probe (Eutech Instruments, Singapore) measured conductivity, dissolved oxygen, $\mathrm{pH}$, resistivity, salinity, total dissolved solids and temperature. Samples of water $(500 \mathrm{~mL})$ were collected in

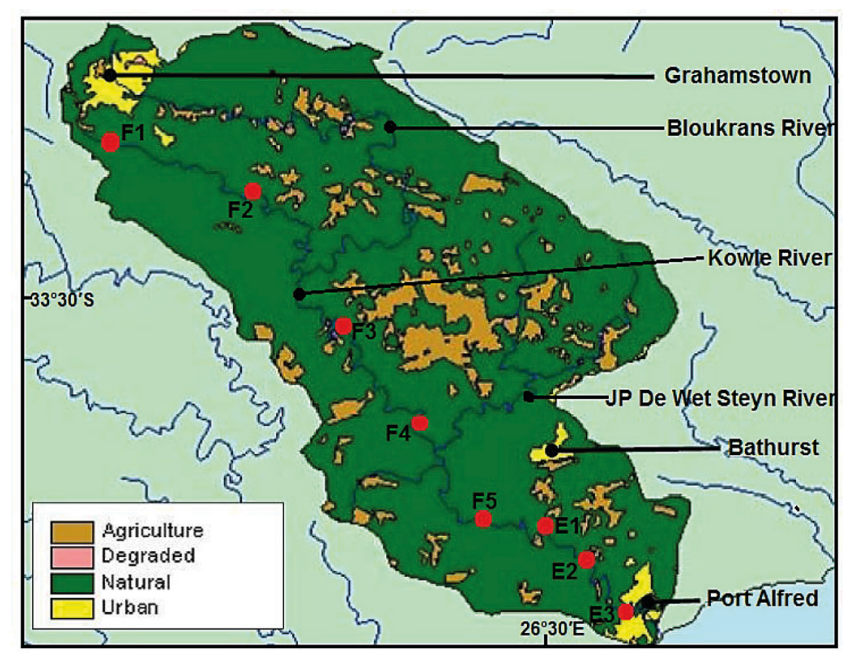

Figure 1

Location of the study sites, in relation to land use characteristics within the Kowie River system triplicate and placed on ice in the dark awaiting further processing in the laboratory for analysis of nutrients (ammonia, phosphates and nitrates),. Nutrient concentrations, employed as proxies for land-use activities, were analysed using a multiparameter bench photometer (HI 83203, Hanna Instruments Inc., Rhode Island) within $12 \mathrm{~h}$ of collection.

\section{Diatom sampling}

Periphyton samples from the river section, Sites F1 to F5, were collected by brushing at least 10 pebble- $(>2-64 \mathrm{~mm})$ to cobble-sized (> 64-256 $\mathrm{mm}$ ) rocks/stones randomly collected from within the channel of the river. Prior to sampling, all rocks were gently shaken in stream water to remove any loosely attached sediment. Epipsammic diatoms from the estuary section of the river were sampled from Sites E1 to E3 due to absence of rocks/stones, by pressing a Petri dish lid into the top layer of silt/clay $(<0.063 \mathrm{~mm})$ to a depth of 5-7 mm, followed by carefully sliding a spatula blade under the Petri dish to isolate the contents in the dish, which were then gently brought to the surface. The periphyton/epipsammic contents were emptied into a labelled container and preserved in Lugol's iodine for microscopic examination in the laboratory. Two days after collection, the benthic diatom samples were digested using the potassium permanganate and hydrochloric acid method following Taylor et al. (2005) and mounted in Pleurax (JC Taylor, North-West University, Potchefstroom) (r.i. 1.73). A total of 300-650 valves per sample (based on counting efficiency determination method by Pappas and Stoermer (1996)) were identified and counted using a phase-contrast microscope (Olympus light microscope, $\times 1$ 000; Model CX21FS1, Olympus Corporation, Tokyo). The diatoms were identified to species level based mainly on studies from South Africa (Taylor et al., 2007).

\section{Data analysis}

A Shapiro-Wilk normality test was carried out to test for the normality of the data so as to satisfy the assumptions of parametric statistical analysis. Since the data violated the ANOVA assumptions, a non-parametric test using ordinal rating (Kruskal-Wallis) was used to test for differences in mean values of physico-chemical variables among study sites and seasons using SPSS 16.0 for Windows software (SPSS Inc., 2007).

\section{Multivariate analysis}

Principal component analysis (PCA) was conducted to derive gradients among physico-chemical factors, with the significance being tested using the Bartlett's test. Multivariate data analyses were then performed on the diatom community dataset to specify the main gradients of floristic variation and to detect and visualize similarities in diatom samples in relation to land use patterns within the catchment. Preliminary de-trended correspondence analysis (DCA) was applied to the diatom community dataset to examine the gradient lengths. The DCA analysis revealed that the gradient lengths were greater than 3 standard deviation units, justifying the use of unimodal ordination techniques (Ter Braak and Verdonschot, 1995). Thus, canonical correspondence analysis (CCA) was used to explore the relationships between diatom communities and predictor variables from different study sites. Preliminary CCA analysis identified collinear variables and selected a subset on inspection of variance inflation factors 
(VIF < 20; ter Braak and Verdonschot, 1995). Monte Carlo permutation tests (999 unrestricted permutations, $p \leq 0.05$ ) were used to test the significance of the axis and hence determine if the selected physico-chemical variables could explain much of the diatom data variation, including all the measured physico-chemical variables combined. Input for the programme included the relative abundance of diatom taxa that were present in a minimum of two samples, with $\geq 1 \%$ relative abundance in at least one sample. PCA was performed using PC-ORD version 5.10 (McCune and Mefford, 2006) and DCA/ CCA were performed using CANOCO version 5.1 (Ter Braak and Šmilauer, 2002).

\section{Diatom indices}

The diatom species counts were entered into OMNIDIA version 5.3 (Lecointe et al., 1993), a diatom database and indices calculation tool. The following indices were calculated: Artois-Picardie Diatom Index (APDI; Prygiel et al., 1996), Biological Diatom Index (BDI; Lenoir and Coste, 1996), Biological Index of Water Quality (BIWQ; Lobo et al., 2004), Commission of Economical Community (CEC; Descy and Coste, 1991), Descy's Pollution Index (DES; Descy, 1979), Eutrophication/Pollution Index (EPI; Dell'Uomo, 1996), Leclercq (IDSE; Leclerq and Maquet, 1987), Pampean Diatom Index (PDI; Gómez and Licuirsi, 2001), Pollution Sensitivity Index (SPI; Coste and Ayphassorho, 1991), Saprobic Index (SI; Rott et al., 1997), Schiefele and Schreiner's Index (SHE; Schiefele and Schreiner 1991), Sládeček's Index (SLA; Sládeček, 1986), Specific Trophic Index (TI; Rott et al., 1999), Trophic Diatom Index (TDI; Kelly and Whitton, 1995), and the Watanabe (WAT; Watanabe et al., 1986). Pearson's correlations between diatom index values and physico-chemical variables were calculated using SPSS 16.0 for Windows software (SPSS Inc., 2007).

\section{RESULTS}

\section{Physico-chemical variables}

The physico-chemical variable values measured during the study period are presented in detail in Dalu et al. (2014c, 2015a, b). Nutrient concentrations showed various patterns along the length of the Kowie River (Fig. 2). Ammonium $\left(\mathrm{NH}_{4}^{+}\right)$concentrations increased from the pristine upstream site, Site F1 $\left(0.14 \pm 0.12 \mathrm{mg} \cdot \mathrm{L}^{-1}\right)$, to sewage-polluted Site E3 $\left(0.59 \pm 0.31 \mathrm{mg} \cdot \mathrm{L}^{-1}\right)$. Elevated nutrient concentrations (nitrate and phosphate) were found at Sites F3 and E3 which were heavily impacted by agriculture and sewage treatment plant discharge (see Fig. 2). Significant seasonal differences were observed for dissolved oxygen $(\mathrm{H}=7.08, p=0.001)$, oxygen reduction potential $(\mathrm{H}=39.15, p<0.001)$ and water flow $(\mathrm{H}=$ $3.72, p=0.024)$, while significant site variation was observed for conductivity $(\mathrm{H}=20.8, p<0.001)$, total dissolved solids $(\mathrm{H}=$ $15.94, p<0.001)$, salinity $(H=18.73, p<0.001)$, water depth $(H$ $=45.47, p<0.001)$ and ammonium $(\mathrm{H}=13.25, p=0.001)$.

Principal component analysis of physico-chemical factors extracted three components with eigenvalues $>1.0$, which accounted for $69.2 \%$ of the variance (Table 1 ). The $1^{\text {st }}$ axis (or factor), accounting for $39.6 \%$ of the variance, separated ammonium, conductivity, nitrates, salinity, total dissolved solids, and water depth with factor loadings $>0.60$. The $2^{\text {nd }}$ axis (or factor) explained $16.7 \%$ of the variance, and was primarily composed of nitrates, temperature and water flow (Tables 1 and 2).

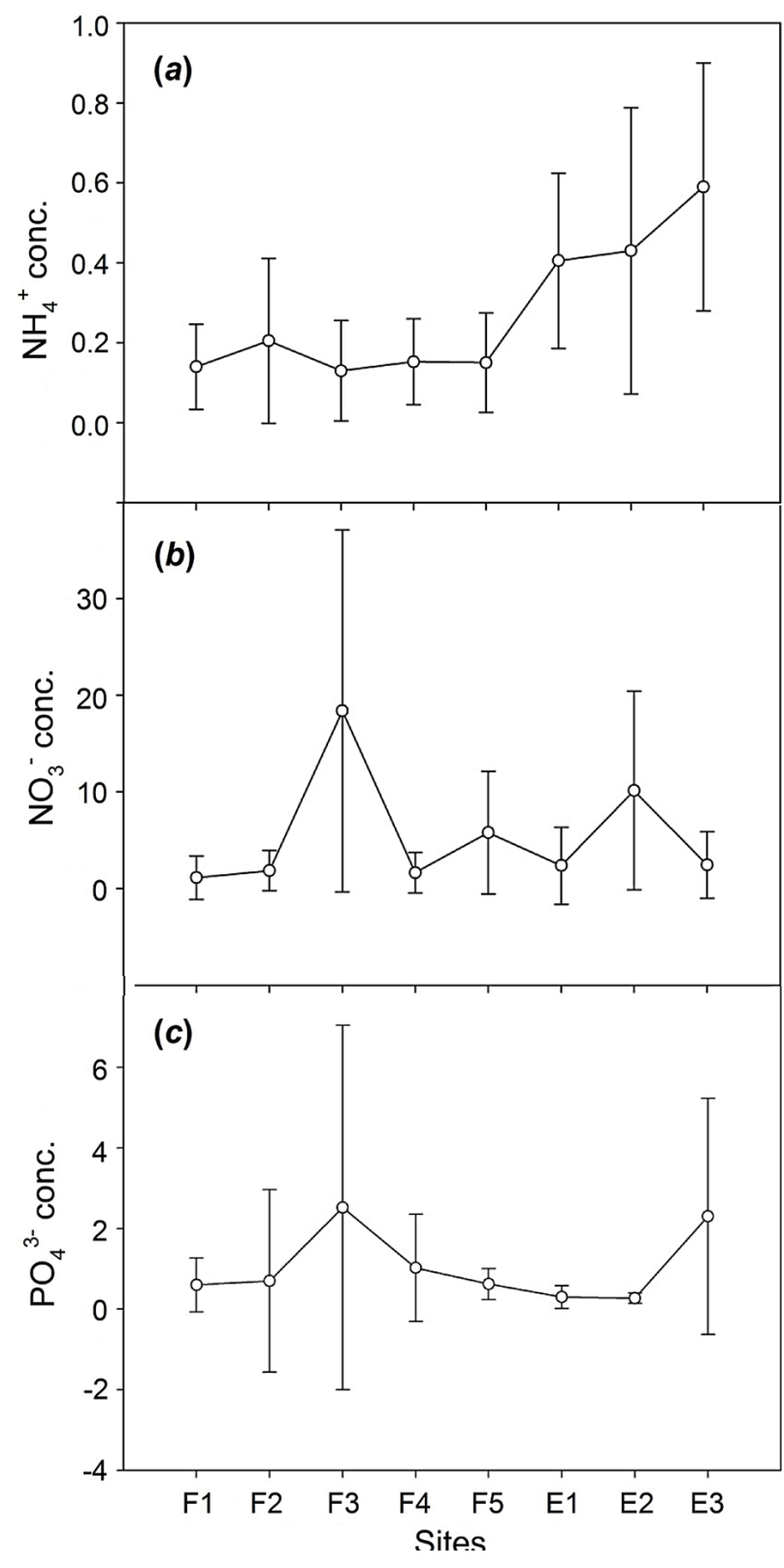

Figure 2

Variation in nutrient concentrations ( \pm standard deviations; $m g \cdot L^{-1}$ ) used as a proxy for land use, within the Kowie River system; (a) ammonium $\left(\mathrm{NH}_{4}^{+}\right),(b)$ nitrates $\left(\mathrm{NO}_{3}^{-}\right)$, and (c) phosphates $\left(\mathrm{PO}_{4}^{3-}\right)$ concentrations (conc.)

TABLE 1

Total variance explained by PCA for physico-chemical variables in the Kowie River, South Africa

\begin{tabular}{|c|c|c|c|}
\hline Axis & Eigenvalue & $\begin{array}{c}\text { \% of } \\
\text { Variance }\end{array}$ & $\begin{array}{c}\text { Cum. \% of } \\
\text { Variance }\end{array}$ \\
\hline 1 & 4.353 & 39.571 & 3.020 \\
\hline 2 & 1.838 & 16.705 & 2.020 \\
\hline 3 & 1.416 & 12.869 & 1.520 \\
\hline 4 & 0.915 & 8.319 & 1.187 \\
\hline
\end{tabular}




\begin{tabular}{|l|c|c|c|c|}
\hline \multirow{6}{*}{$\begin{array}{c}\text { TABLE } 2 \\
\text { First four axes extracted by PCA using 11 physico- } \\
\text { chemical factors in the Kowie River, South Africa. Bold } \\
\text { values indicate significance at } \boldsymbol{p}<\mathbf{0 . 0 5}\end{array}$} \\
\cline { 2 - 5 } \multicolumn{1}{|c|}{ Variable } & $\mathbf{5}$ & $\mathbf{2}$ & $\mathbf{3}$ & $\mathbf{4}$ \\
\cline { 2 - 5 } & $\mathbf{1}$ & - & 0.1973 \\
\hline Ammonium & 0.6841 & 0.0194 & - & - \\
\hline Conductivity & 0.9718 & 0.0558 & 0.1086 & - \\
\hline Nitrates & - & - & 0.2794 & - \\
\hline pH & 0.2326 & 0.0150 & - & - \\
\hline Phosphates & 0.2487 & 0.0202 & - & 0.5901 \\
\hline Water depth & 0.9062 & - & 0.2053 & - \\
\hline Water flow & - & - & - & 0.2069 \\
\hline Resistivity & - & 0.4843 & 0.3324 & 0.4923 \\
\hline Salinity & 0.9564 & 0.0630 & 0.0991 & 0.0146 \\
\hline Temperature & 0.1502 & - & 0.1959 & 0.2415 \\
\hline $\begin{array}{l}\text { Total dissolved } \\
\text { solids }\end{array}$ & 0.9602 & 0.0664 & 0.0760 & - \\
\hline
\end{tabular}

\section{Diatom community structure}

One hundred and twelve (112) diatom species belonging to 36 genera were recorded in total. The mean diatom frequency of occurrence for the dominant taxa across the study period is highlighted in Table 3. Canonical correspondence analysis (CCA) analysis results are presented in Fig. 3 , with the $1^{\text {st }}$ and $2^{\text {nd }}$ axes of the selected exploratory variables accounting for $57.7 \%$ of the total community data variance. Ammonium, nitrate, and conductivity were positively associated with the $1^{\text {st }}$ axis while water flow was negatively associated with the $1^{\text {st }}$ axis (Fig. 3). Temperature and $\mathrm{pH}$ levels were positively associated with the $2^{\text {nd }}$ axis, while resistivity was negatively associated with the $2^{\text {nd }}$ axis.

Multivariate ordination analysis separated the sites into four distinct groupings based on catchment land-use effects (Fig. 3). Group 1 consisted of the upper reaches, Sites F1 and F2, which were considered to be pristine. These sites were associated with high flow, low concentrations of ammonium and nitrates, and lower conductivity (Fig. 3). Sites F1 and F2 were characterised by Fragilaria tenera (W Smith) Lange-Bertalot, Cyclostephanos dubius (Fricke) Round and Gyrosigma acuminatum (Kützing) Rabenhorst. The $2^{\text {nd }}$ group (Group 2) consisted

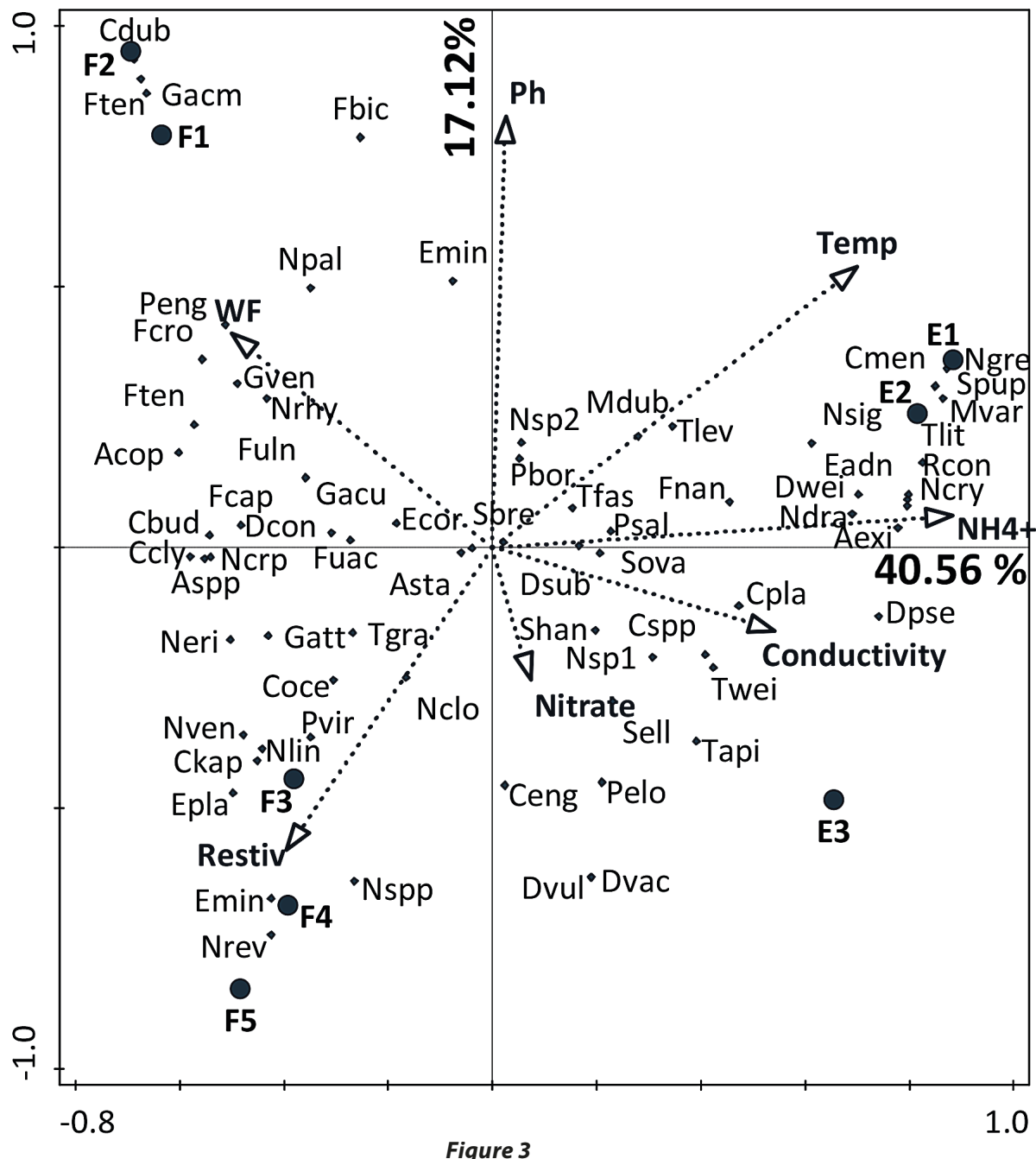

Canonical correspondence analysis (CCA) diagram showing simultaneous effects of physico-chemical variables on most frequently occurring diatom taxa in the ordination space of the $1^{\text {st }}$ and $2^{\text {nd }}$ axes averaged for the four sampling periods. Abbreviations: Restiv - resistivity, $\mathrm{NH}_{4}^{+}-$ammonium, $^{-}$

Temp - temperature, WF-water flow and taxa codes correspond to those in Table 3. 
TABLE 3

Acronyms used in CCA tri-plot and cumulative frequencies. Abbreviations: $+(<1 \%)$, « (>1\% to $4.9 \%), x(>5 \%$ to $9.9 \%)$ and $\times(>10 \%)$. Diatom taxa without codes were not included in the OMNIDIA analysis. Source: Dalu et al. (2015a, b)

\begin{tabular}{|c|c|c|c|c|c|c|c|c|c|}
\hline \multirow{2}{*}{ Species } & \multirow{2}{*}{ Codes } & \multicolumn{8}{|c|}{ Diatom frequency for sites } \\
\hline & & $\mathbf{F 1}$ & $\mathbf{F 2}$ & F3 & $\mathbf{F 4}$ & F5 & E1 & E2 & E3 \\
\hline Achnathes standeri Cholnoky & Asta & & « & & « & + & & & \\
\hline Achnathes sp. & Aspp & + & & & & & + & « & « \\
\hline Achnathidium exiguum (Grunow) Czarnecki & Aexi & & + & $\ll$ & & $\ll$ & & & \\
\hline Amphora copulata (Kützing) Schoeman and Archibald & Acop & & & + & & + & & & \\
\hline Campylodiscus clypeus Ehrenberg & Ccly & & & + & « & + & + & + & « \\
\hline Cocconeis engelbrechtii Cholnoky & Ceng & + & & & & + & + & $«$ & + \\
\hline Cocconeis placentula Ehrenberg & Cpla & & + & & + & + & & & \\
\hline Craticula buderi (Hustedt) & Cbud & & + & « & & & & & \\
\hline Cyclostephanos dubius (Fricke) Round & Cdub & $\ll$ & & & $\ll$ & + & $\ll$ & + & $\ll$ \\
\hline Cyclotella sp. & Cspp & + & & & & & + & + & \\
\hline Cyclotella meneghiniana Kützing & Cmen & + & « & $a$ & $\times$ & « & + & + & + \\
\hline Cyclotella ocellata Pantocsek & Coce & $«$ & + & 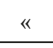 & 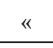 & 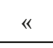 & & & \\
\hline Cymbella kapii (Cholnoky) Cholnoky & Ckap & + & + & « & + & « & & & \\
\hline Diadesmis confervacea (Kützing) DG Mann & Dcon & & & & & « & & & $a$ \\
\hline Diatoma vulgaris Bory & Dvul & + & « & + & « & & « & + & a \\
\hline Diploneis subovalis Cleve & Dsub & & & & & + & & & + \\
\hline Diploneis vacillans (A Schmidt) Cleve & Dvac & « & & + & & & « & « & « \\
\hline Diploneis weissflogii (A Schmidt) Cleve & Dwei & & & & & & + & + & + \\
\hline Discostella pseudostelligera (Hustedt) Houk and Klee & Dpse & & & + & + & « & & & \\
\hline Encyonema minuta (Hilse) DG Mann & Emin & & + & & + & « & & & \\
\hline Entomoneis paludosa (W. Smith) Reimer & Epla & + & « & + & « & + & « & + & + \\
\hline Epithemia adnata (Kützing) Brebisson & Eadn & « & + & & + & & + & & \\
\hline Eunotia minor (Kützing) Grunow & Emin & & & 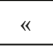 & & + & & & \\
\hline Fallacia tenera (Hustedt) DG Mann & Ften & & « & & & & + & & \\
\hline Fragilaria biceps Ehrenberg & Fbic & $a$ & $\times$ & $\times$ & « & $\times$ & + & & + \\
\hline Fragilaria capucina var. rumpens (Kützing) Lange-Bertalott & Fcap & & + & « & & & & & \\
\hline Fragilaria crotonensis Kitton & Fcro & & & + & & & « & & \\
\hline Fragilaria nanana Lange-Bertalot & Fnan & & $a$ & a & & & & & \\
\hline Fragilaria tenera (W Smith) Lange-Bertalot & Ften & + & & a & « & + & + & + & \\
\hline Fragilaria ulna (Nitzsch) Lange-Bertalot & Fuln & « & $a$ & $a$ & « & $\times$ & + & + & $«$ \\
\hline Fragilaria ulna var. acus (Kützing) Lange-Bertalott & Fuac & $\times$ & $\times$ & « & a & $\times$ & « & « & « \\
\hline Gomphonema acuminatum Ehrenberg & Gacu & + & « & 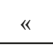 & + & & + & & \\
\hline Gomphonema venusta Passy, Kociolek andLowe & Gven & « & « & 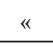 & & & & & \\
\hline Gyrosigma acuminatum (Kützing) Rabenhorst & Gacm & & « & + & + & « & & & + \\
\hline Gyrosigma attenuatum (Kützing) Cleve & Gatt & " & + & " & + & + & + & « & « \\
\hline Melosira dubia Kützing & Mdub & & & & & & a & + & « \\
\hline Melosira varians Argadh & Mvar & & & « & + & « & & & + \\
\hline Navicula sp. & Nspp & + & & & & & + & « & « \\
\hline Navicula cryptocephala Kützing & Ncry & & « & « & « & & & + & + \\
\hline Navicula cryptotenella Lange-Bertalott & Ncrp & + & « & « & $"$ & " & & & \\
\hline Navicula erifuga Lange-Bertalot & Neri & & & & & & + & + & \\
\hline Navicula gregaria Donkin & Ngre & + & « & & + & + & & + & + \\
\hline Navicula rhynchocephala Kützing & Nrhy & & + & & " & + & & & \\
\hline Navicula veneta Kutzing & Nven & & & + & + & & + & & + \\
\hline Nitzschia sp. 1 & Nsp1 & + & + & « & + & & + & 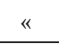 & + \\
\hline Nitzschia sp. 2 & Nsp2 & + & & « & + & $«$ & & + & « \\
\hline Nitzschia closterium (Ehrenberg) W Smith & Nclo & + & & & & & « & $«$ & $«$ \\
\hline Nitzschia draveilensis Coste and Ricard & Ndra & + & & & $«$ & & & & \\
\hline Nitzschia linearis (Agardh) W Smith & Nlin & « & + & & + & & + & & \\
\hline
\end{tabular}




\begin{tabular}{|c|c|c|c|c|c|c|c|c|c|}
\hline \multicolumn{10}{|c|}{ Table 3 (continued) } \\
\hline \multirow{2}{*}{ Species } & \multirow{2}{*}{ Codes } & \multicolumn{8}{|c|}{ Diatom frequency for sites } \\
\hline & & F1 & F2 & F3 & F4 & F5 & E1 & E2 & E3 \\
\hline Nitzschia palea (Kützing) W Smith & Npal & & & & + & + & & & \\
\hline Nitzschia reversa W Smith & Nrev & & + & & & & " & " & " \\
\hline Nitzschia sigma (Kützing) W Smith & Nsig & « & $"$ & + & « & & « & + & \\
\hline Pinnularia borealis Ehernberg sensu lato & Pbor & + & & & & + & & & + \\
\hline Pinnularia viridiformis Krammer & Pvir & « & + & + & + & + & + & & \\
\hline Planothidium engelbrechtii (Cholnoky) Round and Bukhityarova & Peng & & & & & « & + & & « \\
\hline Pleurosigma elongatum $\mathrm{W}$ Smith & Pelo & $x$ & $\alpha$ & $x$ & " & " & $\times$ & $x$ & $x$ \\
\hline Pleurosigma salinarum (Grunow) Grunow & Psal & & & & & & $\times$ & $\times$ & $\times$ \\
\hline Radiofilum conjunctivum Schmidle & Rcon & & & & & & " & $"$ & \\
\hline Sellaphora pupula (Kützing) Mereschkowsky sensu lato & Spup & & & & + & + & + & + & + \\
\hline Staurosira elliptica (Schumann) Williams and Round & Sell & $"$ & + & 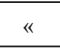 & + & " & « & $"$ & « \\
\hline Stephanodiscus hantzschii Grunow & Shan & & $"$ & + & $"$ & + & + & + & + \\
\hline Surrirella brebissonii Krammer and Lange-Bertalott & Sbre & + & « & + & " & + & a & $"$ & « \\
\hline Surirella ovalis Brebisson & Sova & « & " & + & « & « & $a$ & $\alpha$ & « \\
\hline Tabularia fasciculata (Agardh) Williams et Round & Tfas & & & & " & & + & " & « \\
\hline Thalassiosira weissflogii (Grunow) Fryxell and Hasle & Twei & & & & + & & & $"$ & « \\
\hline Tryblionella apiculata Gregory & Tapi & & + & + & + & + & & + & \\
\hline Tryblionella gracilis W Smith & Tgra & « & & + & + & & + & + & + \\
\hline Tryblionella levidensis W Smith & Tlev & « & & & & & « & & + \\
\hline Tryblionella littoralis (Grunow) DG Mann & Tlit & + & & & & & + & + & + \\
\hline
\end{tabular}

of Sites F3, F4 and F5 that were polluted by the Bloukrans River, which carries discharged effluent from a Grahamstown sewage treatment works and agricultural input from the Belmont Valley area. These sites were negatively associated with the $1^{\text {st }}$ and $2^{\text {nd }}$ axes and were associated with high resistivity and low temperature and $\mathrm{pH}$ (Fig. 3). The diatom community at these three sites was characterised by Cymbella kapii (Cholnoky) Cholnoky, Eunotia minor (Kützing) Grunow, Entomoneis paludosa, Navicula spp., Navicula veneta Kützing, Nitzschia reversa W Smith, and Nitzschia linearis (Agardh) W Smith (Fig. 3).

Group 3 consisted of Site E3 which is highly impacted by sewage effluent discharge from Port Alfred and was positively associated with ammonium, nitrates and conductivity. The diatoms Tryblionella apiculata Gregory, Pleurosigma elongatum W Smith, Diploneis vacillans (Ant Schmidt) Cleve, Diatoma vulgaris Bory and Staurosira elliptica (Schumann) Williams and Round were associated with Site E3 (Fig. 3).The fourth, and last, group consisted of the moderately impacted Sites E1 and E2, associated with high temperature and ammonium and low resistivity (Fig. 3). These sites were associated with Cyclotella meneghiniana Kützing, Melosira varians Argadh, Navicula gregaria Donkin, Nitzschia sigma (Kützing) W Smith, and Tryblionella littoralis (Grunow) DG Mann (Fig. 3).

\section{Diatom indices}

Of the total 112 diatom species identified, 97 species were listed in OMNIDIA. As a consequence, only these species were included in the calculation of the various diatom indices. The omitted taxa were either uncommon in the areas where the indices were developed or were planktonic forms (e.g. Amphora, Discostella) (Table 4). The trends in the different diatom indices were broadly similar with low values recorded in the upper reaches, intermediate values in the middle and elevated values in the lower section of the system (Table 5). The CCA ordination analysis (see Fig. 3) was similar to the calculated diatom indices, although a number of the indices, e.g., DI-CH, TDI, EPI and BIWQ, either under- or over-estimated the water quality of the system (Table 5). Pearson correlation analysis indicated that conductivity, $\mathrm{pH}$, resistivity, salinity, total dissolved solids (TDS), and water depth were significantly correlated $(p<0.05)$ with the majority of the index scores. This is in contrast to the other physico-chemical variables (Table 5). The physico-chemical variables which typically were associated with poor water quality, including ammonium $\left(\mathrm{NH}_{4}^{+}\right)$, nitrates $\left(\mathrm{NO}_{3}^{-}\right)$and phosphates $\left(\mathrm{PO}_{4}{ }^{3-}\right)$ ions, were only significantly correlated with either one of the diatom indices, e.g., the SHE, DICH and BIWQ (Table 5). No significant correlations $(p>0.05)$ were observed for CEC, GDI, PDI, SI, TI and WAT diatom indices with physico-chemical variables, but APDI, BDI, and BIWQ diatom indices showed significant correlations (Table 5).

\section{DISCUSSION}

In agreement with studies conducted elsewhere (e.g. Lobo et al., 2004; Ndiritu et al., 2006; Taylor et al., 2007; Bellinger et al., 2009; Bere et al., 2014, Hlúbiková et al., 2014; Tan et al., $2014 \mathrm{a}, \mathrm{b})$, the current study indicates that benthic diatom communities can be a useful tool for water quality monitoring since the diatom communities recorded changed in response to land-use patterns and anthropogenic activities. Most of the sites along the length of the river, excluding the upstream sites, were subjected to point-source pollution from the catchment, which resulted in the species distribution being strongly biased towards cosmopolitan diatom species (e.g. Fragilaria ulna, Gomphonema acuminatum) and those that are tolerant to pollution (Nitzschia linearis, N. palea and N. reversa). 
TABLE 4

Diatom index scores recorded for the Kowie system: APDI - Artois-Picardie Diatom Index, EPI - Eutrophication/Pollution Index, BDI - Biological Diatom Index, SHE - Schiefele and Schreiner's Index, SI - Saprobic Index, TI - Trophic Index, WAT

- Watanabe Index, SPI - Specific Pollution Sensitivity Index, SLA - Sládeček's Index, DES - Descy's Pollution Index, IDSE

- Leclercq Index, CEC - Commission of Economical Community Index, TDI - Trophic Diatom Index, PDI - Pampean Diatom Index, BIWQ - Biological Index of Water Quality.

\begin{tabular}{|c|c|c|c|c|c|c|c|c|c|}
\hline \multirow{2}{*}{ Indices } & \multirow{2}{*}{ Trophic } & \multicolumn{8}{|c|}{ Sites } \\
\hline & & F1 & $\mathbf{F 2}$ & F3 & F4 & F5 & E1 & E2 & E3 \\
\hline SLA & 0 (best) to 4 (worse) & $1.8 \pm 0.1$ & $1.9 \pm 0.1$ & $2.2 \pm 0.1$ & $2.14 \pm 0.1$ & $1.9 \pm 0.3$ & $2.2 \pm 0.3$ & $2.2 \pm 0.2$ & $2.1 \pm 0.2$ \\
\hline DES & 1 (worst) to 5 (best) & $2.9 \pm 0.7$ & $3.3 \pm 0.5$ & $3.3 \pm 0.3$ & $3.1 \pm 0.2$ & $2.8 \pm 0.5$ & $3.1 \pm 0.8$ & $3.2 \pm 0.5$ & $3.9 \pm 0.4$ \\
\hline IDSE & 1 (worst) to 5 (best) & $3.4 \pm 0.1$ & $3.3 \pm 0.2$ & $2.9 \pm 0.1$ & $2.9 \pm 0.2$ & $3.3 \pm 0.3$ & $2.7 \pm 0.3$ & $2.9 \pm 0.5$ & $3 \pm 0.3$ \\
\hline SHE & 1 (worst) to 7 (best) & $5 \pm 0.1$ & $5.2 \pm 0.3$ & $4.7 \pm 0.6$ & $4.7 \pm 0.2$ & $4.8 \pm 0.5$ & $4.8 \pm 0.4$ & $4.9 \pm 0.6$ & $4.9 \pm 0.5$ \\
\hline WAT & 0 (worst) to 100 (best) & $53.9 \pm 5.1$ & $50.6 \pm 10.1$ & $46.8 \pm 11.14$ & $42.4 \pm 10.2$ & $44.7 \pm 21$ & $51.6 \pm 2.7$ & $38.6 \pm 25.8$ & $52.9 \pm 3.8$ \\
\hline TDI & 0 (best) to 100 (worst) & $48.1 \pm 18$ & $66.7 \pm 10.8$ & $67 \pm 12$ & $73.8 \pm 2.7$ & $56.7 \pm 5.7$ & $60.5 \pm 11.2$ & $74.2 \pm 6.4$ & $78.9 \pm 15$ \\
\hline CEC & 0 (worst) to 10 (best) & $3.5 \pm 2.4$ & $6.2 \pm 1.6$ & $3.1 \pm 0.7$ & $3.6 \pm 0.9$ & $3.8 \pm 2.7$ & $2.3 \pm 2.8$ & $2 \pm 2.3$ & $1.3 \pm 2.5$ \\
\hline SPI & 1 (worst) to 5 (best) & $3.6 \pm 0.4$ & $3.2 \pm 0.4$ & $3 \pm 0.3$ & $2.8 \pm 0.3$ & $3.3 \pm 0.5$ & $2.2 \pm 0.3$ & $2.2 \pm 0.3$ & $2.4 \pm 0.3$ \\
\hline BDI & 1 (worst) to 7 (best) & $4.4 \pm 0.2$ & $4.4 \pm 0.2$ & $4.1 \pm 0.03$ & $4 \pm 0.3$ & $4.3 \pm 0.2$ & $3.3 \pm 0.4$ & $3.5 \pm 0.5$ & $3.8 \pm 0.2$ \\
\hline APDI & 1 (worst) to 5 (best) & $3 \pm 0.1$ & $3 \pm 0.8$ & $2.8 \pm 0.7$ & $2.6 \pm 0.5$ & $2.9 \pm 0.4$ & $2 \pm 0.7$ & $2.4 \pm 0.3$ & $2.3 \pm 0.3$ \\
\hline EPI & 0 (best) to 4 (worst) & $1.7 \pm 0.2$ & $1.9 \pm 0.4$ & $2.3 \pm 0.2$ & $2.3 \pm 0.3$ & $1.8 \pm 0.6$ & $2.7 \pm 0.2$ & $2.5 \pm 0.3$ & $2.3 \pm 0.2$ \\
\hline $\mathrm{DICH}$ & 1 (best) to 8 (worst) & $5.1 \pm 0.4$ & $4.6 \pm 1.1$ & $4.9 \pm 0.4$ & $4.9 \pm 0.5$ & $5.5 \pm 0.8$ & $4.4 \pm 1.3$ & $4.8 \pm 0.7$ & $4.7 \pm 0.3$ \\
\hline PDI & 0 (best) to 4 (worst) & $2.1 \pm 0.3$ & $2.3 \pm 0.4$ & $2.6 \pm 0.2$ & $2.5 \pm 0.2$ & $2.3 \pm 0.3$ & $2.4 \pm 0.4$ & $2.6 \pm 0.4$ & $2.2 \pm 0.1$ \\
\hline BIWQ & 1 (best) to 4 (worst) & $3.1 \pm 0.5$ & $2.9 \pm 0.2$ & $2.7 \pm 0.3$ & $2.8 \pm 0.2$ & $2.8 \pm 0.4$ & $1.7 \pm 0.5$ & $1.9 \pm 0.5$ & $2.3 \pm 0.4$ \\
\hline SI & 1 (best) to 3.8 (worst) & $2.2 \pm 0.3$ & $1.9 \pm 0.4$ & $2.1 \pm 0.4$ & $2.3 \pm 0.5$ & $2 \pm 0.3$ & $2.5 \pm 0.3$ & $2.2 \pm 0.5$ & $2.1 \pm 0.1$ \\
\hline TI & 0.3 (best) to 3.9 (worst) & $2.7 \pm 0.1$ & $2.6 \pm 0.2$ & $2.9 \pm 0.2$ & $2.9 \pm 0.2$ & $2.7 \pm 0.4$ & $3.2 \pm 0.3$ & $2.9 \pm 0.7$ & $3.2 \pm 0.1$ \\
\hline
\end{tabular}

TABLE 5

Pearson correlation coefficients between measured physico-chemical variables and diatom index scores generated for Kowie system. Significance (bold values) at ${ }^{*} p<0.05$ and ${ }^{*} p<0.01$. Abbreviation, TDS - total dissolved solids, ammonium $\left(\mathrm{NH}_{4}{ }^{+}\right)$, phosphate $\left(\mathrm{PO}_{4}{ }^{3-}\right)$, nitrate $\left(\mathrm{NO}_{3}{ }^{-}\right)$and abbreviations for indices see Table 4.

\begin{tabular}{|l|c|c|c|c|c|c|c|c|c|c|c|}
\hline & TDS & Salinity & Resistivity & Temperature & $\begin{array}{c}\text { Water } \\
\text { depth }\end{array}$ & Velocity & Ammonia & Phosphates & Nitrate & Conductivity & pH \\
\hline SLA & - & - & 0.09 & 0.07 & - & 0.12 & - & 0.16 & 0.09 & - \\
\hline DES & - & - & - & 0.15 & - & 0.17 & - & - & $0.37^{*}$ & - \\
\hline IDSE & $0.47^{* *}$ & $0.44^{* *}$ & - & 0.09 & $0.47^{* *}$ & 0.12 & 0.13 & 0.04 & - & $0.46^{* *}$ & 0.28 \\
\hline SHE & 0.19 & 0.17 & - & - & 0.16 & - & 0.19 & - & - & 0.20 & 0.04 \\
\hline WAT & 0.14 & 0.17 & - & - & 0.19 & - & 0.17 & - & 0.16 & 0.19 & - \\
\hline TDI & - & - & - & - & - & - & - & - & 0.23 & - & 0.04 \\
\hline GDI & 0.12 & 0.13 & 0.09 & 0.01 & 0.22 & 0.05 & - & 0.00 & - & 0.13 & 0.03 \\
\hline CEC & 0.13 & 0.10 & - & 0.07 & 0.25 & - & 0.00 & - & - & 0.14 & 0.12 \\
\hline SPI & $0.59^{* *}$ & 0.57 & - & 0.10 & $0.63^{* *}$ & - & 0.33 & 0.15 & - & $0.59^{* *}$ & $0.35^{*}$ \\
\hline BDI & $0.48^{* *}$ & $0.45^{*}$ & - & 0.19 & $0.55^{* *}$ & 0.12 & 0.29 & 0.12 & - & $0.48^{* *}$ & $0.45^{*}$ \\
\hline APDI & $0.38^{*}$ & $0.34^{*}$ & - & - & $0.37^{*}$ & 0.13 & 0.27 & 0.01 & - & $0.37^{*}$ & $0.38^{*}$ \\
\hline EPI & - & - & 0.34 & - & - & 0.11 & - & 0.06 & 0.12 & - & - \\
\hline DICH & 0.12 & 0.13 & 0.09 & - & 0.10 & - & 0.17 & $0.37^{*}$ & - & 0.12 & 0.33 \\
\hline PDI & - & - & 0.02 & 0.01 & - & - & 0.01 & - & 0.05 & - & - \\
\hline BIWQ & $0.46^{* *}$ & $0.41^{*}$ & - & 0.12 & $0.51^{* *}$ & - & $0.36^{*}$ & - & - & $0.47^{* *}$ & $0.45^{*}$ \\
\hline SI & 0.06 & 0.06 & 0.33 & - & - & - & 0.03 & 0.07 & - & 0.02 & - \\
\hline TI & - & - & 0.33 & - & - & 0.11 & - & 0.02 & 0.10 & - & - \\
\hline
\end{tabular}




\section{Physico-chemical factors influencing diatom communities}

Benthic diatom community structure in freshwater systems is determined by the interaction of proximate determinants such as nutrients (e.g. nitrates and phosphorus), intermediate factors (e.g. longitudinal linkages), and ultimate factors (e.g. climate, geohydromorphology, and land use) (Lavoie et al., 2008; Bere et al., 2014; Dalu et al., 2014a, b; Tan et al., 2014a, b). The CCA analysis for the Kowie River benthic diatom communities demonstrated that ammonium, conductivity, temperature, $\mathrm{pH}$, resistivity and water flow (water velocity) best explained the variation in the diatom community structure. Ammonium and nitrate concentrations were identified as the main primary factors. This finding is in agreement with a study conducted in parallel to the present study by Dalu et al. (2014a, b; 2015a, b). In our study, we hypothesized that the influence of elevated nutrients derived from anthropogenic activities would have an impact on the diatom community structure. The increased nutrient levels recorded at Sites F3 to F5 and E1 to E3, derived from human activities, contributed to the predominance of nutrient-tolerant taxa such as Navicula veneta, Nitzschia linearis and Tryblionella apiculata (Fig. 3). These findings are similar to those of Hlúbiková et al. (2014), who found that prolonged nutrient enrichment at moderate concentrations had an effect on diatom composition in four streams in the western highlands eco-region of Luxembourg, with studies by Lobo et al. (2004), Ndiritu et al. (2006) and Mangadze et al. (2015) observing similar outcomes. In addition to nutrient availability, water flow was also identified as an important factor in structuring diatom communities in this study, which again is consistent with previous studies conducted both locally and internationally (e.g. Ruth, 1977; Biggs et al., 2005; Song, 2007; Tan et al., 2014b; Bere et al., 2013; Dalu et al., 2014a).

The PCA analysis of the physico-chemical factors extracted seven components with eigenvalues $>1.0$, with a total variance of $69.15 \%$; the components comprised ammonium, conductivity, nitrate, phosphate, salinity, total dissolved solids, and water depth. These findings suggest that other proximate factors (e.g. substratum) and/or ultimate factors (e.g. land use and/or cover) likely also influenced the benthic diatom community structure and distribution in the Kowie River system. Tan et al. (2014b) also observed similar findings in the Han River, where he suggested that factors such as substratum, ultimate factors (i.e. land use) and biological pressure such as predation (i.e. grazing) could have smaller effects on the spatial diatom community structure pattern. In this study, we observed that land use, based on nutrients as proxy, probably contributes more to the diatom community structure temporal pattern because ultimate factors operate at catchment scales over a long period of time. Therefore, future studies should assess the relationships that exist between physico-chemical factors and benthic diatoms in river systems that are heavily influenced by anthropogenic impacts, and also those that are un-impacted (natural), so as to have a better understanding of the forces at play.

\section{Water quality status assessed by diatom indices}

Diatom indices have been used extensively for water pollution and trophic status assessment in America, Asia and Europe (Descy, 1979; Leclerq and Maquet, 1987; Prygiel et al., 1996; Rott et al., 1997; Tan et al., 2014b; Venkatachalapathy and Karthikeyan, 2015) and are slowly being introduced in several
African countries (Bate et al., 2002; Bellinger et al., 2006; Taylor et al., 2007a, b; Bere et al., 2013). On the African continent, several studies have assessed the applicability of the indices developed in America, Europe and Australasia e.g. CEE, IPS, EPI-D, IBD, IPS, TDI, and WAT in sub-Saharan Africa (Bellinger et al., 2006; Taylor et al., 2007a, b; Walsh and Wepener, 2009; Bere et al., 2014).

In the current study, only BIWQ, DES and DICH diatom indices were significantly correlated to ammonium, nitrate and phosphate concentrations. These results are in stark contrast to previous studies conducted in Asia (Tan et al., 2014b; Venkatachalapathy and Karthikeyan, 2015), Europe (Leclerq and Maquet, 1987; Prygiel et al., 1996), Kenya (Bellinger et al., 2006), South Africa (Taylor et al., 2007a, b; Walsh and Wepener, 2009) and Zimbabwe (Bere et al., 2014). It is, however, worth noting that the absence of any significant correlations between diatom index values and macronutrient concentrations during this investigation is consistent with similar studies conducted within the Crocodile, Vaal and Wilge Rivers in South Africa (Taylor et al., 2007a, b). Interestingly the trophic diatom index (TDI) was insensitive to eutrophication (ammonium, nitrates and phosphates) but was significantly correlated with other physico-chemical variables. It is important to note, however, that the diatom community at the time of sampling may have been exposed to different nutrient concentrations prior to those recorded during the study. Ideally, nutrient concentrations in the water column should be assessed prior to diatom sampling although this may not be logistically or economically feasible. In addition, conductivity and salinity might have overriding effects on nutrient concentration in this case. This observation demonstrates the limitation of employing indices developed elsewhere and, hence, the need for calibration or local adaption or development of indices unique to the study region, as environmental optima and tolerance ranges may vary in different climates (Lobo et al., 2004; Bellinger et al., 2006; Lavoie et al., 2009). Bate et al. (2004) observed that most of the common and dominant diatom taxa found in South African rivers were already recorded in the international literature. He went on to conclude that most foreign diatom indices may be used in tropical systems as they are based on the diatom ecology of cosmopolitan and widely distributed taxa (Taylor et al., 2005). However, there is a concern over comparison of diatom species and autecological preferences between Northern and Southern Hemispheres (Round, 1991). The universal application of diatom indices may, therefore, not always yield consistent results, as highlighted in this study and others (e.g. Gómez and Licursi, 2001; Lavoie et al., 2009).

Fifteen diatom species, constituting about $13 \%$ of the recorded taxa, some of them likely endemic to the region of study, were not included in OMNIDIA. These rare species or endemic diatoms currently not listed in OMNIDIA may provide a better tool for local water quality assessment (Lobo et al., 2004; Bere et al., 2014). The ecological preferences of these endemic and rare species should therefore be determined and incorporated in the calculation of the indices for a better assessment of stream biological integrity in Southern Africa.

\section{CONCLUSION}

We have demonstrated that land-use activities within the Kowie River catchment impacted on the water quality, with ammonium, nitrate and phosphate concentrations closely reflecting the urban and agricultural activities within the catchment. The changes in the physico-chemical parameters 
of the water column were associated with shifts in the diatom community composition along the length of the river. Diatombased water quality indices calculated during this investigation were, with few exceptions (e.g. DES and BIWQ), not significantly correlated to ambient nutrient concentrations (Table 4). The absence of any significant correlations between the diatom index values and nutrient concentrations may reflect the fact that the diatom indices e.g. the CEC, GDI and TDI developed in other regions of the world may not be suitable for temperate African streams. Consequently it is proposed that diatom indices should be developed within the region, after investigations on the diatom nutrient tolerances and preferences have been carried out. This will greatly improve water quality analysis based on diatom indices.

\section{ACKNOWLEDGEMENTS}

We thank the two anonymous reviewers for their useful and insightful comments. This study was financially supported by the Water Research Commission, National Research Foundation and the Rhodes University Sandisa Imbewu Initiative. Tatenda Dalu is a Rhodes University Postdoctoral Fellow. We thank Jeff Hean, Katherina Schoo, Matthew Parkinson, Lenin Chari, Leandro Bergamino, Simphiwe Gininda, Likho Sikutshwa, Sydney Moyo and Jakob Katzenberger for their assistance in the field.

\section{REFERENCES}

BAHLS LL (1993) Periphyton bioassessment methods for Montana streams. Montana Department of Health and Environmental Sciences, Helena, MT.

BATE GC, ADAMS JB and VAN DER MOLEN JS (2002) Diatoms as indicators of water quality in South African river systems. WRC Report No. 814/1/02. Water Research Commission, Pretoria.

BATE GC, SMAILES PA and ADAMS JB (2004) A water quality index for use with diatoms in the assessment of rivers.

BELLINGER BJ, COCQUYT C and O'REILLY CM (2006) Benthic diatoms as indicators of eutrophication in tropical streams. Hydrobiologia 573 75-87. http://dx.doi.org/10.1007/ s10750-006-0262-5

BERE T, MANGADZE T and MWEDZI T (2014) The application and testing of diatom-based indices of stream water quality in Chinhoyi Town, Zimbabwe. Water SA 40 530-512. http://dx.doi.org/10.4314/ wsa.v40i3.14

BERE T, PHIRI C, KADYE WT and UTETE B (2013) Benthic diatom assemblages in mountain streams: community structure in relation to environmental and human pressures. Afr. J. Ecol. 51 625-634. http://dx.doi.org/10.1111/aje.12078

BERE T and TUNDISI JG (2011) The effects of substrate type on diatom-based multivariate water quality assessment in a tropical river (Monjolinho), São Carlos, SP, Brazil. Water Air Soil Pollut. 216 391-409. http://dx.doi.org/10.1007/s11270-010-0540-8

BEŠTA T, MUŠKA M, JUGGINS S and TĚŠITEL J (2015) Comparison of diatom community structure from epilithon and fish guts: implications for inferring past changes in water quality. Hydrobiologia 742 233-248. http://dx.doi.org/10.1007/s10750-014-1987-1

BIGGS BJ F, NIKORA VI and SNELDER TH (2005) Linking scales of flow variability to lotic ecosystem structure and function. River Res. Appl. 21 283-298. http://dx.doi.org/10.1002/rra.847

COSTE M and AYPHASSORHO H (1991) É tude de la qualité dês eaux du Bassin Artois-Picardie à l'aide des communaute's de diatomées benthiques (application des índices diatomiques). Rapport Cemagref, Bordeaux. Agence de l'Eau Artois-Picardie, Douai.

DALU T, FRONEMAN PW, CHARI LD and RICHOUX NB (2014a) Colonisation and community structure of benthic diatoms on artificial substrates following a major flood event: A case of the Kowie River (Eastern Cape, South Africa). Water SA 40 471-480. http:// dx.doi.org/10.4314/wsa.v40i3.10

DALU T, FRONEMAN PW and RICHOUX NB (2014c) Phytoplankton community diversity along a river-estuary continuum. Trans. R. Soc. S. Afr. 69 107-116. http://dx.doi.org/10.1080/00359 19X.2014.930074

DALU T, RICHOUX NB and FRONEMAN PW (2014b) An assessment, using multivariate analysis and stable isotopes, of the effects of substrate type on phytobenthos communities. Inland Waters 4 397-412. http://dx.doi.org/10.5268/IW-4.4.719

DALU T, BERE T, RICHOUX NB and FRONEMAN PW (2015a) Assessment of the spatial and temporal variation in periphyton communities along a small temperate river system: a multimetric and stable isotope analysis approach. S. Afr. J. Bot. 100 203-212. http://dx.doi.org/10.1016/j.sajb.2015.05.028

DALU T, RICHOUX NB and FRONEMAN PW (2015b) Distribution of benthic diatom communities in a permanently open temperate estuary, in relation to physico-chemical variables. S. Afr. J. Bot. DOI:10.1016/j.sajb.2015.06.002. http://dx.doi.org/10.1016/j. sajb.2015.06.002

DELL'UOMO A (1996) Assessment of water quality of an Apennine river as a pilot study. In: Whitton BA and Rott E (eds) Use of Algae for Monitoring Rivers II. Institut für Botanik, Universität Innsbruck, Innsbruck.

DESCY JP (1979) A new approach to water quality estimation using diatoms. Nova Hedwig. 64 305-323.

DESCY JP and COSTE M (1991) A test of methods for assessing water quality based on diatoms. Verh. Int. Ver. Theor. Angew. Limnol. 24 2112-2116.

EUROPEAN COMMISSION (2000) Directive 2000/60/EC of the European Parliament and of the Council of 23rd October 2000 establishing a framework for Community action in the field of water policy. Official J. Eur. Commun. 327 1-72.

GÓMEZ N and LICURSI M (2001) The Pampean Diatom Index (Idp) for assessment of rivers and streams in Argentina. Aquat. Ecol. 35 173-181. http://dx.doi.org/10.1023/A:1011415209445

HLÚBIKOVÁ D, NOVAIS MH, DOHET A, HOFFMANN L and ECTOR L (2014) Effect of riparian vegetation on diatom assemblages in headwater streams under different land uses. Sci. Total Environ. 475 234-247. http://dx.doi.org/10.1016/j. scitotenv.2013.06.004

KELLY MG and WHITTON BA (1995) The trophic diatom index: a new index for monitoring eutrophication in rivers. J. Appl. Phycol.7 433-444. http://dx.doi.org/10.1007/BF00003802

LAVOIE I, CAMPEAU S, ZUGIC-DRAKULIC N, WINTER JG and FORTIN C (2014) Using diatoms to monitor stream biological integrity in Eastern Canada: An overview of 10 years of index development and on-going challenges. Sci. Total Environ. 475 187-200. http://dx.doi.org/10.1016/j.scitotenv.2013.04.092

LAVOIE S, CAMPEAU S, DARCHAMBEAU F, CABANA F and DILLON PJ (2008) Are diatoms good integrators of temporal variability in stream water quality? Freshwater Biol. 53 827-841. http:// dx.doi.org/10.1111/j.1365-2427.2007.01935.x

LAVOIE I, HAMILTON P, WANG YK, DILLON PJ and CAMPEAU S (2009) A comparison of stream bioassessment in eastern Canada using six North American and European diatom-based indices. Nova Hedwig. Beihefte 134 37-56.

LECLERQ L and MAQUET B (1987) Deux nouveaux índices chimique et diatomique de qualité d'eau courante: Application au Samson et à ses affluents (bassin de la Meuse belge). Comparaison avec d'autres índices chimiques, biocénotiques et diatomiques. Institut Royal des Sciences Naturelles de Belgique, document de travail 28.

LECOINTE C, COSTE M and PRYGIEL J (1993) 'Omnidia': Software for taxonomy, calculation of diatom indices and inventories management. Hydrobiologia 269/270 509-513. http://dx.doi. org/10.1007/BF00028048

LELAND HV and PORTER SD (2000) Distribution of benthic algae in the upper Illinois River basin in relation to geology and land use. Freshwater Biol. 44 279-301. http://dx.doi. org/10.1046/j.1365-2427.2000.00536.x

LENOIR A and COSTE M (1996) Development of a practical diatom index of overall water quality applicable to the French National Water Board network. In: Whitton BA and Rott E (eds.) Use of 
Algae for Monitoring Rivers II. Institut für Botanik, Universität Innsbruck.

LOBO EA, CALLEGARO VL, HERMANY G, BES D, WETZEL CE and OLIVEIRA MA (2004) Use of epilithic diatoms as bioindicator from lotic systems in southern Brazil, with special emphasis on eutrophication. Acta Limnol. Bras. 16 25-40.

MANGADZE T, BERE T and MWEDZI T (2015) Epilithic diatom flora in contrasting land-use settings in tropical streams, Manyame Catchment, Zimbabwe. Hydrobiologia. DOI: 10.1007/ s10750-015-2203-2207.

MANN DG and DROOP SJM (1996) Biodiversity, biogeography and conservation of diatoms. Hydrobiologia 336 19-32. http://dx.doi. org/10.1007/BF00010816

MCCUNE B and MEFFORD MJ (2006) PC-ORD: Multivariate Analysis of Ecological Data. Version 5.10. MjM Software, Gleneden Beach (OR), USA.

MEYNENDONCKX J, HEUVELMANS G, MUYS B and FEYEN $J$ (2006) Effects of watershed and riparian zone characteristics on nutrient concentrations in the River Scheldt Basin. Hydrol. Earth Syst. Sci. Discuss. 3 653-679. http://dx.doi.org/10.5194/ hessd-3-653-2006

MISTRI M, MUNARI C and MARCHINI A (2008) The fuzzy index of ecosystem integrity (FINE): a new index of environmental integrity for transitional ecosystems. Hydrobiologia 611 81-90. http://dx.doi. org/10.1007/s10750-008-9455-4

NDIRITU GG, GICHUKI NN and TRIEST L (2006) Distribution of epilithic diatoms in response to environmental conditions in an urban tropical stream, Central Kenya. Biodiv. Conserv.15 32673293. http://dx.doi.org/10.1007/s10531-005-0600-3

PAPPAS JL and STOERMER EF (1996) Formulation of a method to count number of individuals' representative of number of species in algal communities. J. Phycol. 32 693-196. http://dx.doi. org/10.1111/j.0022-3646.1996.00693.x

PRYGIEL J, LÉVÉQUE L and ISERENTANT R (1996) Un nouvel indice diatomique pratique pour l'évaluation de La qualité des eaux en réseau de surveillance. Rev. Sci. l'Eau 1 97-113.

RIMET F, BOUCHEZ A and MONTUELLE B (2015) Benthic diatoms and phytoplankton to assess nutrients in a large lake: Complementarity of their use in Lake Geneva (FranceSwitzerland). Ecol. Indic. 53 231-239. http://dx.doi.org/10.1016/j. ecolind.2015.02.008

ROTT E, HOFMANN G, PALL K, PFISTER P and PIPP E (1997) Indikationslisten für Aufwuchsalgen. Teil 1. SaprobielleIndikation. Bundesministeriumfür Land- und Forstwirtschaft, Wien. 1-73.

ROTT E, PIPP E, PFISTER P, VAN DAM H, ORTLER K, BINDER $\mathrm{N}$ and PALL K (1999) Indikationslistenfür Aufwuchsalgen in ö sterreichischen Fliessgewässern. Teil 2: Trophieindikation (sowiegeochemische Präferenzen; taxonomische und toxikologische Anmerkungen). Wasserwirtschaftskataster herasgegeben vom Bundesministerium f. Land- u. Forstwirtschaft, Wien.

ROUND FE (1991) Diatoms in river water-monitoring studies. J. Appl. Phycol. 3 129-145. http://dx.doi.org/10.1007/BF00003695

RUTH P (1977) Ecology of freshwater: diatoms and diatom communities. In: WERNER D (ed.) The Biology of Diatoms. Blackwell Scientific, London.

ALMEIDA SFP, ELIAS C, FERREIRA J, TORNÉS E, PUCCINELLI C, DELMAS F, DÖRFLINGER G, URBANIČ G, MARCHEGGIANI S, ROSEBERY J, MANCINI L and SABATER S (2014) Water quality assessment of rivers using diatom metrics across Mediterranean Europe: A methods intercalibration exercise. Sci. Total Environ. 476-477 768-776. http://dx.doi.org/10.1016/j.scitotenv.2013.11.144

SCHIEFELE S and SCHREINER C (1991) Use of diatoms for monitoring nutrient enrichment acidification and impact salts in Germany and Austria. In: Whitton BA, Rott E and Friedrich G (ed.) Use of Algae for Monitoring Rivers. Institüt für Botanik, Univ. Innsbruck, Innsbruck.

SCHOWE KA and HARDING JS (2014) Development of two diatombased indices: a biotic and a multimetric index for assessing mine impacts in New Zealand streams. New Zealand J. Mar. Freshwat. Res. 48 163-176. http://dx.doi.org/10.1080/00288330.2013.852113

SLÀDEČEK V (1986) Diatoms as indicators of organic pollution. Acta Hydrochim. Hydrobiol. 14 555-566. http://dx.doi.org/10.1002/ aheh.19860140519
SONG X (2007) Trends in benthic algal community response to a small-scale gradient of current velocities along a streambed transect. MSc thesis, Graduate College of Bowling Green State University, Bowling Green, USA.

SPSS INC. (2007) SPSS Release 16.0.0 for Windows. Polar Engineering and Consulting. SPSS Inc., Chicago (IL).

STEVENSON RJ and PAN YD (1999) Assessing environmental conditions in rivers and streams with diatoms. In: Stoermer EF and Smol JP (eds) The Diatoms: Applications for the Environmental and Earth Sciences. Cambridge University Press, Cambridge, UK. http:// dx.doi.org/10.1017/CBO9780511613005

TAN X, MA P, BUNN SE and ZHANG Q (2015) Development of a benthic diatom index of biotic integrity (BD-IBI) for ecosystem health assessment of human dominant subtropical rivers, China. J. Environ. Manage. 151 286-294. http://dx.doi.org/10.1016/j. jenvman.2014.12.048

TAN X, MA P, XIA X and ZHANG Q (2014b) Spatial pattern of benthic diatoms and water quality assessment using diatom indices in a subtropical river, China. Clean 42 20-28. http://dx.doi. org/10.1002/clen.201200152

TAN X, XIA X, ZHAO Q and ZHANG Q (2014a) Temporal variations of benthic diatom community and its main influencing factors in a subtropical river, China. Environ. Sci. Pollut. Res. 21 434-444. http://dx.doi.org/10.1007/s11356-013-1898-0

TAYLOR JC, DE LA REY PA and VAN RENSBURG L (2005) Recommendations for the collection, preparation and enumeration of diatoms from riverine habitats for water quality monitoring in South Africa. Afr. J. Aquat. Sci. 30 65-75. http://dx.doi. org/10.2989/16085910509503836

TAYLOR JC, JANSE VAN VUUREN MS and PIETERSE AJH (2007a) The application and testing of diatom-based indices in the Vaal and Wilge rivers, South Africa. Water SA 33 51-60.

TAYLOR JC, PRYGIEL J, VOSLOO A, DE LA REY PA and VAN RENSBURG L (2007b) Can diatom-based pollution indices be used for biomonitoring in South Africa? A case study of the Crocodile West and Marico water management area. Hydrobiologia 592 455-464. http://dx.doi.org/10.1007/s10750-007-0788-1

TAYLOR JC, HARDING WR and ARCHIBALD CGM (2007c) An illustrated guide to some common diatom species from South Africa. WRC Report No. TT 282/07. Water Research Commission, Pretoria.

TER BRAAK CJF and ŠMILAUER P (2002) CANOCO Reference Manual and CanoDraw for Windows User's Guide: Software for Canonical Community Ordination (version 4.5). Microcomputer Power, Ithaca, NY.

TER BRAAK CJF and VERDONSCHOT PFM (1995) Canonical correspondence analysis and related multivariate methods in aquatic ecology. Aquat. Sci. 57 255-289. http://dx.doi.org/10.1007/ BF00877430

VENKATACHALAPATHY R and KARTHIKEYAN P (2015) Diatom indices and water quality index of Cauvery River, India: Implications on the suitability of bio-indicators for environmental impact assessment. In: Ramkumar MU, Kumaraswamy K and Mohanraj R (eds) Environmental Management of River Basin Ecosystems. Springer Earth System Sciences, Switzerland. http:// dx.doi.org/10.1007/978-3-319-13425-3_31

VÖRÖSMARTY CJ, MCINTYRE PB, GESSNER MO, DUDGEON D, PRUSEVICH A, GREEN P, GLIDDEN S, BUNN SE, SULLIVAN CA, LIERMANN CR and DAVIES PM (2010) Global threats to human water security and river biodiversity. Nature $467555-561$. http://dx.doi.org/10.1038/nature09440

WALSH G and WEPENER V (2009) The influence of land use on water quality and diatom community structures in urban and agriculturally stressed rivers. Water SA 35 579-594. http://dx.doi. org/10.4314/wsa.v35i5.49184

WATANABE T, ASAI K and HOUKI A (1986) Numerical estimation of organic pollution of flowing waters by using the epilithic diatom assemblage - Diatom Assemblage Index (DIApo). Sci. Total Environ. 55 209-218. http://dx.doi. org/10.1016/0048-9697(86)90180-4

WINTER JG and DUTHIE HC (2000) Epilithic diatoms as indicators of stream total $\mathrm{N}$ and total P concentration. J. N. Am. Benthol. Soc. 19 32-49. http://dx.doi.org/10.2307/1468280 
WU N, CAI Q and FOHRER N (2012) Development and evaluation of a diatom-based index of biotic integrity (D-IBI) for rivers impacted by run-of-river dams. Ecol. Indic. 18 108-117. http://dx.doi. org/10.1016/j.ecolind.2011.10.013

ZALACK JT, SMUCKER NJ and VIS ML (2010) Development of a diatom index of biotic integrity for acid mine drainage impacted streams. Ecol. Indic. 10 287-295. http://dx.doi.org/10.1016/j. ecolind.2009.06.003

ZELINKA M and MARVAN P (1961) Zur Prazisierung der biologischen Klassifikation der Reinheit fliessender Gewässer. Arch. Hydrobiol. 57 389-407. 